\title{
Reproductive Aspects of Haemaphysalis leporis-palustris
}

\author{
Marcelo Bahia Labruna ${ }^{+}$, Romário Cerqueira Leite
}

\begin{abstract}
Departamento de Medicina Veterinária Preventiva, Escola de Veterinária, Universidade Federal de Minas Gerais,
\end{abstract} Caixa Postal 567, 31270-901 Belo Horizonte, MG, Brasil

The adult stage of Haemaphysalis leporis-palustris was studied. Two infestations consisted of male and female ticks on two rabbits (Oryctolagus cuniculus). Other two infestations consisted of only female ticks on two O. cuniculus. Females fed without males showed differences in some biological parameters when compared to females fed with males. Parthenogenesis is reported for the first time by one $\mathrm{H}$. leporis-palustris female.

Key words: Haemaphysalis leporis-palustris - Ixodidae - biology - parthenogenesis

Few tick species reproduce successfully by parthenogenesis, as Amblyomma rotundatum in the tropical and subtropical areas of New World and some populations of Haemaphysalis longicornis in Oceania and East Asia. Therefore the majority of Ixodidae and Argasidae species are normally bisexual. Sporadic parthenogenesis is reported in normally bisexual tick species: Ornithodoros verrucosus, O. papillipes, O. moubata (Balashov 1972), Dermacentor variabilis, Boophilus microplus, Hyalomma anatolicum, Rhipicephalus bursa, Amblyomma dissimile (Oliver 1989), B. microplus (Ribeiro \& Gonzales 1980). The present work is about the biology of the adult stage and verifies the occurence of parthenogenesis in a tick sample from a normally bisexual population of $H$. leporis-palustris.

\section{MATERIALS AND METHODS}

Ticks - A laboratory colony of H. leporispalustris was established from an engorged nymph and an adult male collected from a rabbit Sylvilagus brasiliensis live-trapped on Belo Horizonte, State of Minas Gerais. Ticks were indentified as $H$. leporis-palustris (Packard 1869) according to Cooley (1946). Ticks were taken to a biochemestry oxygen demand (B.O.D.) cabinet at $27^{\circ} \mathrm{C}$ and relative humidity superior to $85 \%$, where the engorged nymph molted to a female. Some days later this female and the male were allowed to feed on a rabbit Oryctolagus cuniculus. After natural detachment from the rabbit the engorged female laid eggs that produced a generation of larvae. This generation of ticks was used in successive infestations on

This work was supported by CAPES.

${ }^{+}$Corresponding author. Fax: +55-31-441.9918

Received 24 June 1996

Accepted 22 January 1997
O. cuniculus and S. brasiliensis in laboratory originating engorged nymphs. Each individual engorged nymph was observed for molting in the B.O.D. cabinet. Ticks were identified according to the sex on the day that each one completed molting to adult. Adult males were put in a covered tube labelled as $\mathrm{Y}$ and adult females were put in another covered tube labelled as $\mathrm{X}$. When adult ticks were 8 to 20 days old, and no adult had had contact with adults of the other sex, 12 males were put together with 14 females in another covered tube labelled as $\mathrm{X}+\mathrm{Y}$. This was the first contact of adult males with adult females. Eleven males remained in the $\mathrm{Y}$ tube and 15 females in the $\mathrm{X}$ tube.

Infestations - When adults were 18 to 30 days old, they were used in 4 infestations, each one on a different $O$. cuniculus with no previous tick infestation. Infestation 1: 10 males and 7 females from the $\mathrm{X}+\mathrm{Y}$ tube were allowed to feed on an $\mathrm{O} . \mathrm{Cu}$ niculus. Infestation 2: 7 females from $\mathrm{X}+\mathrm{Y}$ tube were allowed to feed on an $O$. cuniculus. Infestation 3: 10 males from $Y$ tube and 7 females from $\mathrm{X}$ tube were allowed to feed on an $O$. cuniculus. Infestation 4: 7 females from $X$ tube were allowed to feed on an $O$. cuniculus.

Each $O$. cuniculus was observed daily for engorged female natural detatchment. Records were made of the parasitic time in days for each engorged female and its weight in an electronic balance. On the same day, the females were individually transferred to a B.O.D. cabinet under the same conditions mentioned above where they were observed for pre-oviposition and oviposition periods. If females oviposited, their egg output was observed daily in the B.O.D. cabinet to determine the incubation period and the hatching period. The incubation period consisted of time taken from the first day of oviposition until the first emergence of larva from the total egg output of each female. The hatching period consisted of time from the emergence 
of the first to the last larva from the total egg output of each female. The hatching success of eggs (\% hatching) was determinated in 5-5\% intervals by visual estimating of hatched eggs in a stereoscopic microscope, according to Leite (1988). The index of reproductive efficiency (IRE) was calculated for the females that layed eggs, according to the formula (Deamon \& Freire 1984):

$$
\text { IRE }=\frac{\text { total egg output weight }(\mathrm{g})}{\text { total female weight }(\mathrm{g})} \times 100
$$

\section{RESULTS}

The engorged females recovered in each infestation and the parasitic period and non-parasitic data from these females and their egg output are presented in Tables I, II, III and IV.

\section{DISCUSSION}

Females from infestations 2 and 4 parasitized for a longer period but engorged less than those from infestations 1 and 3. It probably resulted from the absence of males during the feeding period in infestations 2 and 4 . This agrees with the findings of Balashov (1972), Norval et al. (1980), Ribeiro and Gonzales (1980), Ntiamoa-Baidu (1987), Oliver (1989), working with various ixodid Metastriata species. Balashov (1972) said that absence of males during Metastriata female feeding increases the slow feeding period and there is no defined rapid feeding period as in copulated female feeding. This author also said that many of the females fed without males laid fewer eggs than females fed with males. Balashov (1972) said that ovary enlargement is slow in non-copulated females and when these females detach, their ova-

TABLE I

Parasitic and non-parasitic data of Haemaphysalis leporis-palustris females recovered from infestation 1 on Oryctolagus cuniculus and egg data from these females

\begin{tabular}{cccccccccc}
\hline \multicolumn{7}{c}{ Infestation 1: 10 males and 7 females from the tube X+Y } \\
\hline Females & $\begin{array}{c}\text { Parasitic } \\
\text { time } \\
\text { (days) }\end{array}$ & $\begin{array}{c}\text { Engorged } \\
\text { weight } \\
\text { (mg) }\end{array}$ & $\begin{array}{c}\text { Pre- } \\
\text { oviposition } \\
\text { period } \\
\text { (days) }\end{array}$ & $\begin{array}{c}\text { Oviposition } \\
\text { period } \\
\text { (days) }\end{array}$ & $\begin{array}{c}\text { Egg output } \\
\text { weight } \\
\text { (mg) }\end{array}$ & $\begin{array}{c}\text { Incubation } \\
\text { period } \\
\text { (days) }\end{array}$ & $\begin{array}{c}\text { Hatching } \\
\text { period } \\
\text { (days) }\end{array}$ & $\begin{array}{c}\text { Hatching } \\
(\%)\end{array}$ & $\begin{array}{c}\text { Index of } \\
\text { reproductive } \\
\text { efficiency } \\
(\%)\end{array}$ \\
\hline 1 & 14 & 417 & 4 & 20 & 256 & 34 & 22 & 99 & 61.4 \\
2 & 15 & 370 & 4 & 23 & 185 & 34 & 21 & 80 & 50.0 \\
3 & 15 & 355 & 5 & 22 & 190 & 32 & 24 & 70 & 53.5 \\
4 & 17 & $n$ & - & - & - & - & - & - & - \\
5 & 18 & 237 & nn & - & - & - & - & - & - \\
\hline Mean & 15.8 & 344.7 & 4.3 & 21.6 & 210 & 33.3 & 22.3 & 83 & 54.9 \\
\hline
\end{tabular}

n: female dead by accident; nn: female did not lay eggs

TABLE II

Parasitic and non-parasitic data of Haemaphysalis leporis-palustris females recovered from infestation 2 on Oryctolagus cuniculus and egg data from these females

\begin{tabular}{cccccccccc}
\hline \multicolumn{10}{c}{ Infestation 2: 7 females from the tube X+Y } \\
\hline Females & $\begin{array}{c}\text { Parasitic } \\
\text { time } \\
\text { (days) }\end{array}$ & $\begin{array}{c}\text { Engorged } \\
\text { weight } \\
(\mathrm{mg})\end{array}$ & $\begin{array}{c}\text { Pre- } \\
\text { oviposition } \\
\text { period } \\
\text { (days) }\end{array}$ & $\begin{array}{c}\text { Oviposition } \\
\text { period } \\
\text { (days) }\end{array}$ & $\begin{array}{c}\text { Egg output } \\
\text { weight } \\
(\mathrm{mg})\end{array}$ & $\begin{array}{c}\text { Incubation } \\
\text { period } \\
\text { (days) }\end{array}$ & $\begin{array}{c}\text { Hatching } \\
\text { period } \\
\text { (days) }\end{array}$ & $\begin{array}{c}\text { Hatching } \\
(\%)\end{array}$ & $\begin{array}{c}\text { Index of } \\
\text { reproductive } \\
\text { efficiency } \\
(\%)\end{array}$ \\
\hline 1 & 17 & 374 & 4 & 26 & 212 & 53 & 42 & $<5$ & 56.7 \\
2 & 20 & 245 & 8 & 14 & 34 & nh & - & - & 13.9 \\
3 & 21 & 42 & $n n$ & - & - & & - & - & - \\
4 & 21 & 113 & 9 & 15 & 36 & nh & - & - & 31.8 \\
5 & 22 & 112 & 10 & 13 & 17 & nh & - & - & 15.2 \\
6 & 23 & $\mathrm{n}$ & & - & - & - & - & - & - \\
\hline Mean & 20.6 & 177.2 & 7.7 & 17 & 74.7 & 53 & 42 & $<5$ & 29.4 \\
\hline
\end{tabular}

$\mathrm{n}$ : female dead by accident; nn: female did not lay eggs; nh: no egg hatched 
TABLE III

Parasitic and non-parasitic data of Haemaphysalis leporis-palustris females recovered from infestation 3 on Oryctolagus cuniculus and egg data from these females

\begin{tabular}{cccccccccc}
\hline \multicolumn{7}{c}{ Infestation 3: 10 males from the tube Y and 7 females from the tube X } \\
\hline Females & $\begin{array}{c}\text { Parasitic } \\
\text { time } \\
\text { (days) }\end{array}$ & $\begin{array}{c}\text { Engorged } \\
\text { weight } \\
\text { (mg) }\end{array}$ & $\begin{array}{c}\text { Pre- } \\
\text { oviposition } \\
\text { period } \\
\text { (days) }\end{array}$ & $\begin{array}{c}\text { Oviposition } \\
\text { period } \\
\text { (days) }\end{array}$ & $\begin{array}{c}\text { Egg output } \\
\text { weight } \\
\text { (mg) }\end{array}$ & $\begin{array}{c}\text { Incubation } \\
\text { period } \\
\text { (days) }\end{array}$ & $\begin{array}{c}\text { Hatching } \\
\text { period } \\
\text { (days) }\end{array}$ & $\begin{array}{c}\text { Hatching } \\
(\%)\end{array}$ & $\begin{array}{c}\text { Index of } \\
\text { reproductive } \\
\text { efficiency } \\
(\%)\end{array}$ \\
\hline 1 & 14 & 368 & 5 & 18 & 220 & 37 & 24 & 85 & 59.8 \\
2 & 14 & 332 & 5 & 20 & 206 & 34 & 30 & 50 & 62.0 \\
3 & 14 & 374 & 4 & 20 & 233 & 35 & 30 & 60 & 62.3 \\
4 & 14 & 248 & 6 & 22 & 145 & 36 & 18 & 55 & 56.2 \\
5 & 14 & $\mathrm{n}$ & & - & - & - & - & - & 60 \\
\hline Mean & 14 & 330.5 & 5 & 20 & 201 & 35.5 & 25.5 & 62.5 & 60 \\
\hline
\end{tabular}

$\mathrm{n}$ : female dead by accident

TABLE IV

Parasitic and non-parasitic data of Haemaphysalis leporis-palustris females recovered from infestation 4 on Oryctolagus cuniculus and egg data from these females

\begin{tabular}{cccccccccc}
\hline \multicolumn{10}{c}{ Infestation 4: 7 females from the tube X } \\
\hline Females & $\begin{array}{c}\text { Parasitic } \\
\text { time } \\
\text { (days) }\end{array}$ & $\begin{array}{c}\text { Engorged } \\
\text { weight } \\
(\mathrm{mg})\end{array}$ & $\begin{array}{c}\text { Pre- } \\
\text { oviposition } \\
\text { period } \\
\text { (days) }\end{array}$ & $\begin{array}{c}\text { Oviposition } \\
\text { period } \\
\text { (days) }\end{array}$ & $\begin{array}{c}\text { Egg output } \\
\text { weight } \\
(\mathrm{mg})\end{array}$ & $\begin{array}{c}\text { Incubation } \\
\text { period } \\
(\text { days })\end{array}$ & $\begin{array}{c}\text { Hatching } \\
\text { period } \\
\text { (days) }\end{array}$ & $\begin{array}{c}\text { Hatching } \\
(\%)\end{array}$ & $\begin{array}{c}\text { Index of } \\
\text { reproductive } \\
\text { efficiency } \\
(\%)\end{array}$ \\
\hline 1 & 21 & 144 & 5 & 24 & 62 & 61 & 3 & $<1$ & 43.1 \\
2 & 27 & 265 & 6 & 20 & 105 & nh & - & 39.6 \\
\hline Mean & 24 & 204 & 5.5 & 22 & 83.5 & 61 & 3 & $<1$ & 41.3 \\
\hline
\end{tabular}

nh: no egg hatched

ries are much smaller than copulated females, which could justify the low mean IRE found for females from infestations 2 and 4, when compared with infestations 1 and 3.

A few eggs from one female from infestation 2 and one female from infestation 4 hatched and some larvae were obtained. As females from infestation 4 had no contact with males either before or during feeding, it can be concluded that larvae obtained from female 1 from infestation 4 (Table IV) were originated by parthenogenesis. The same can not be said for female 1 from infestation 2 (Table II) as this female had contact with males before feeding. Although many authors report that Metastriata ticks do not copulate before feeding (Balashov 1972, Oliver et al. 1974, Kettle 1984, Oliver 1989), there is one report for Amblyomma triguttatum in which unfed males copulated successfully with unfed females (Guglielmone \& Moorhouse 1983). The present work is the first report of this sporadic type parthenogenesis for a normally bisexual population of a Haemaphysalis species, which occurred similar to other reports of parthenogenesis for normally bisexual ixodid species: i.e. despite the majority of eggs not hatching, a few eggs developed, hatched and originated weak larvae that died in few days (Balashov 1972, Ribeiro \& Gonzales 1980, Oliver 1989). Oliver (1989) reported that despite this sporadic type parthenogenesis is of little pratical significance as most of the few larvae produced are unable to feed, it is of potential evolutionary significance since these tick populations could serve as new material for natural selection.

The parasitic periods of females from infestation 1 and 3 (fed together with males) were generally shorter than the reported in the literature by other authors working with geographical different populations of $H$. leporis-palustris. Rhor (1909) reported this period ranging from 19 to 25 days and Diamant and Strickland (1965) reported it ranging from 17 to 35 days. Therefore these authors did not report the host species in which the females fed what makes not possible to conclude if these 
differences are due to host species or a character regard to different tick populations. The non-parasitic data reported by these authors are not comparable to data from the present work as these works were conduced under different environment conditions.

\section{REFERENCES}

Balashov YS 1972. Bloodsucking ticks (Ixodoidea) Vectors of diseases of man and animals. Miscellaneous Publications of the Entomological Society of America 8: 160-376.

Cooley RA 1946. The genera Boophilus, Rhipicephalus and Haemaphysalis (Ixodidae) of the New World. National Institute of Health, Washington D.C., 54 pp.

Deamon E, Freire NMS 1984. Biologia de Anocentor nitens Neumann, 1987: fase não parasitária em condições de laboratório. Rev Bras Med Vet 6: 181183.

Diamant G, Strickland RK 1965. Manual on Livestock Ticks; for Animal Disease Eradication Division Personel. U.S.D.A., Hyattsville, 142 pp.

Guglielmone AA, Moorhouse DE 1983. Copulation and successful insemination by unfed Amblyomma triguttatum triguttatum Koch. J Parasitol 69: 786787.
Kettle DS 1984. Medical and Veterinary Entomology. Croom Helm, Sydney, 658 pp.

Leite RC 1988. Boophilus microplus (Canestrini, 1887) - Susceptibilidade, uso atual e retrospectivo de carrapaticidas em propriedades das regióes fisiográficas da Baixada do Grande Rio e Rio de Janeiro. Uma abordagem epidemiológica. $\mathrm{PhD}$ Thesis, Universidade Federal Rural do Rio de Janeiro, $151 \mathrm{pp}$.

Norval RAI, Colborne J, Tannock J, Mackenzie PKI 1980. The life cycle of Amblyomma tholloni Neumann, 1899 (Acari: Ixodidae) under laboratory conditions. Vet Parasitol 7: 255-263.

Ntiamoa-Baidu Y 1987. Rhipicephalus simpsoni (Acari-Ixodidae). Development under controlled conditions. J Med Entomol 24: 438-443.

Oliver Jr JH 1989. Biology and systematics of ticks (Acari: Ixodida). Annu Rev Ecol Syst 20: 397-430.

Oliver Jr JH, Al-Ahmadi Z, Osburn RL 1974. Reproduction in ticks (Acari: Ixodoidea). 3. Copulation in Dermacentor occidentalis Marx and Haemaphysalis leporis-palustris (Packard) (Ixodidae). J Parasitol 60: 499-506.

Ribeiro VLS, Gonzales JC 1980. A partenogênese no Boophilus microplus. Arq Fac Vet UFRGS 8: 93108.

Rohr CJ 1909. Estudos sobre Ixódidas do Brasil. Instituto Oswaldo Cruz, Rio de Janeiro, $220 \mathrm{pp}$. 